\title{
Türkiye'de Emzirme Sürecinde Uygulanan Nonfarmakolojik Yöntemler ile İlgili Yapılmış Lisansüstü Tezlerin İncelenmesi
}

\author{
Resmiye KAYA ODABAŞ ${ }^{1}$, (iD Yasemin SÖKMEN ${ }^{2}$, (iD) Ayten TAŞPINAR ${ }^{3}$
}

'Arş. Gör., Kocaeli Üniversitesi, Sağlık Bilimleri Fakültesi, Ebelik Bölümü, Kocaeli, Türkiye.

2Öğr. Gör., Ondokuz Mayıs Üniversitesi, Sağlık Bilimleri Fakültesi, Ebelik Bölümü, Samsun, Türkiye.

${ }^{3}$ Aydın Adnan Menderes Üniversitesi, Sağlık Bilimleri Fakültesi, Ebelik Bölümü, Aydın, Türkiye.

\section{$\ddot{O} z$}

Giriş: Nonfarmakolojik yöntemler ile laktasyonun arttırılması ve meme sorunlarının giderilmesi emzirme ve emzirmenin devamlılığı açısından önemlidir. Amaç: Bu çalışma, Türkiye'de emzirme sürecinde uygulanan nonfarmakolojik yöntemler ile ilgili lisansüstü tezleri incelemek amacıyla yapılmıştır. Yöntem: Araştırma, 12 Ocak-22 Nisan 2021 tarihleri arasında, literatüre dayalı olarak tanımlayıcı nitelikte yapılmış olup, verilerin toplamasında doküman analizi tekniği kullanılmıştır. Lisansüstü tezlere ulaşmak için, "laktasyon", "anne sütü", "meme”, "emzirme" ve "nonfarmakolojik yöntem" anahtar kelimeleri ile Yüksek Öğretim Kurulu Ulusal Tez Merkezi üzerinden tarama yapılmış ve 31 tez incelenmiştir. Veriler, Tez Değerlendirme Formu ile toplanmış, tanımlayıcı istatistikler yoluyla çözümlenmişsir. Bulgular: Çalışmadaki lisansüstü tezlerin, 9'unun Hemşirelik, 7'sinin Ebelik Anabilim Dalı'nda yapıldığı, emzirme sürecinde, yenidoğana uygulanan nonfarmakolojik yöntemlerin; kanguru bakımı ( $\mathrm{n}=10)$, müzik dinletisi $(\mathrm{n}=5)$, emzik verme $(\mathrm{n}=2)$, emzirme destek sistemi $(\mathrm{n}=1)$, oral stimülasyon $(\mathrm{n}=1)$ ve bebek masaj1 $(n=1)$ olduğu, anneye uygulanan nonfarmakolojik yöntemlerin; progresif gevşeme egzersizi $(n=2)$, müzik dinletisi $(n=2)$, ayak masaj1 $(n=1)$, lahana uygulaması $(n=1)$, yatak içi egzersiz $(n=1)$, oksitosin masajı $(n=1)$, akupresür $(n=1)$, bebeğin videosunun izletilmesi $(n=1)$, oral hidrasyon $(n=1)$, sakız çiğneme $(n=1)$ ve transkütan elektriksel sinir stimülasyonu $(n=1)$ olduğu, meme sorunlarına yönelik uygulanan nonfarmakolojik yöntemlerinde; anne sütü $(n=4)$, zeytinyağ $(n=3)$, lahana $(n=1)$, ayva çekirdeği $(n=1)$, hidrojel ped $(n=1)$, sicak kompres $(n=1)$, sıcak çay kompresi uygulaması $(n=1)$, göğüs kalkanı $(n=1)$ ve memeyi temiz kuru tutma $(n=1)$ olduğu bulunmuştur. Sonuç: Emzirme sürecinde uygulanan nonfarmakolojik yöntemlerle ilgili tezlerde, kanguru bakımı/ten tene temas, müzik dinletisi, progresif gevşeme egzersizi ve anne sütü uygulamasının daha çok çalışıldığı, yatak içi egzersiz, erken oral stimülasyon ve sakız çiğneme dışındaki uygulamaların emzirme sürecinde etkili olduğu saptanmıştır.

Anahtar Sözcükler: Laktasyon, Anne Sütü, Meme, Emzirme, Nonfarmakolojik Yöntem.

\section{Abstract \\ Development of Medication Adminstration Self-Efficacy Scale in Children for Nursing Students and Psychometric Properties s}

Backround: Increasing lactation and eliminating breast problems using non-pharmacological methods are important for both breastfeeding, the continuity of breastfeeding. Objectives: This study was conducted examine postgraduate theses non-pharmacological methods used during breastfeeding in Turkey. Methods: The research was conducted as descriptive research based literature between January 12-April 22,2021. Data was collected using document analysis technique. In order to access postgraduate theses, the keywords:"lactation","breast milk","breast", "breastfeeding","non-pharmacological method" were searched National Thesis Center of Council of Higher Education. Data were collected with Thesis Evaluation Form and analyzed using descriptive statistics. Results: Of the postgraduate theses in study, 9 them were Department of Nursing and 7 them Department of Midwifery, non-pharmacological methods used for newborns during breastfeeding included skin-to-skin contact $(n=10)$, music performance $(n=5)$, the use pacifiers $(n=2)$, breastfeeding support system $(n=1)$, oral stimulation $(n=1)$, baby massage $(n=1)$, non-pharmacological methods used facilitate breastfeeding, increase lactation included progressive relaxation exercise $(n=2)$, music performance $(n=2)$, foot massage $(n=1)$, cabbage application $(n=1)$, in-bed exercise $(n=1)$, oxytocin massage $(n=1)$, acupressure $(n=1)$, watching baby's video $(n=1)$, oral hydration $(n=1)$, chewing gum $(n=1)$, transcutaneous electrical nerve stimulation $(n=1)$, the use of breast milk $(n=4)$, olive oil $(n=3)$, cabbage $(n=1)$, quince seed $(n=1)$, hydrogel pad $(n=1)$, hot compress $(n=1)$, hot tea compress $(n=1)$, breast shield $(n=1)$, keeping the breast clean dry $(n=1)$ were found non-pharmacological methods intended breast problems. Conclusion: While among non-pharmacological methods, kangaroo care, music performance, progressive relaxation exercise and breast milk application were found to have been studied more; practices other than in-bed exercise, early oral stimulation, chewing gum were found to effective for breastfeeding process.

Key Words: Lactation, Breast Milk, Breastfeeding, Non-pharmacological Method.

Geliş Tarihi / Received: 24.05.2021 Kabul Tarihi / Accepted:.31.12.2021

Correspondence Author: Araş. Gör., Kocaeli Üniversitesi, Sağlık Bilimleri Fakültesi, Ebelik Bölümü, Kocaeli, Türkiye. E-posta: resmiye.odabas@ gmail.com. Cite This Article: Kaya Odabaş R, Sökmen Y, Taşpnar A. Türkiye’de Emzirme Sürecinde Uygulanan Nonfarmakolojik Yöntemler İle İlgili Yapılmış Lisansüstü Tezlerin İncelenmesi. Dokuz Eylül Üniversitesi Hemşirelik Fakültesi Elektronik Dergisi. 2022; 15(1): 56-67. 

i nsanın yaşamını derinlemesine etkileyen bebeklik dönemi, beslenme açısından büyük bir öneme sahiptir (1). Bu dönemde anne sütü; doğumdan itibaren ilk altı aylık süreçte, bebek için gerekli tüm besin maddelerini içeren, bebeğin sağlıklı bir şekilde büyüyüp gelişmesini sağlayan, bebek morbidite ve mortalite oranlarını azaltan doğal bir besindir $(2,3)$. Ayrıca, başta beslenme olmak üzere, gelişimsel, psikolojik ve immünolojik olarak tüm sistemlere yönelik sağlı̆ğ devamını sağlarken, toplumsal, sosyal ve ekonomik açıdan da birçok faydası bulunmaktadır (4-7). Bu yüzden anne sütü altın standart olarak kabul edilmekte ve Dünya Sağlık Örgütü (World Health Organization-WHO) tarafindan doğumdan sonra ilk altı ay sadece anne sütüyle beslenme önerilmektedir (8).

Dünyada yenidoğanların ilk bir saat içinde emzirilme oranı $\% 44$ ve ilk altı ayda sadece anne sütü ile beslenme oranı $\% 40$ olarak bildirilmektedir. İlk bir saat içinde emzirilme oranının $\% 70$ 'e ve ilk altı ay sadece anne sütü ile beslenme oranının ise \%50'nin üzerine çıarılması hedeflenmektedir $(3,9)$. Türkiye Nüfus ve Sağlık Araștırmaları (TNSA-2018) raporuna göre, yenidoğanın ilk bir saat içinde emzirilme oranı \%71 ve ilk altı ay sadece anne sütü ile beslenme oranı \%41'dir (10). Ülkemizde ilk bir saat içinde emzirme oranı yüksek iken, ilk altı aylık süreçte annelerin emzirmeyi bıraktıkları görülmektedir. Annelerin genellikle emzirmeyi bırakma nedenleri arasında en başta yetersiz süt üretimi gelirken bunu sırasıyla, bebeğin emmemesi/emmede güçlük çekmesi ve tek başına anne sütünün bebeğin doymasında yeterli olmaması takip etmektedir (11). Bununla birlikte anneler emzirme süresince bazı sorunlarla da karşılaşabilmektedir. Bunların başında, düz/çökük meme ucu, meme dolgunluğu (engorjman), meme başında hassasiyet/ağrı, çatlak meme ucu, yetersiz süt salınımı, tıkanmış süt kanalları, mastit, meme absesi ve memede enfeksiyon gelmekte ve tüm bunlar emzirmeyi olumsuz yönde etkileyerek annelerin emzirmeyi bırakmalarına neden olmaktadır $(12,13)$.

Emzirme sürecine ilişkin yaşanan sorunların en kısa zamanda çözümlenmesi, anne ve bebek sağlı̆̆ açısından ele alınması gereken önemli bir konudur. Bu nedenle laktasyonu arttırmak ve meme sorunlarının giderilmesi için nonfarmakolojik yöntemler hem emzirme hem de emzirmenin devamlılığı açısından önemlidir (14). Laktasyonu arttırmak için yapılan uygulamalar; kanguru bakımı, sırt masajı, yoga, meme masajı, kompresyon, akupunktur, akupresür, gevşeme egzersizleri, müzik terapi, aromaterapi, bitkisel çay kullanımı, galaktagoglar ve hipnoemzirme teknikleridir $(15,16)$. Emzirmeye bağlı oluşan meme sorunlarının giderilmesinde kullanılan yöntemler ise; zeytinyağı, lanolin krem, nane jeli, aloe vera jeli, hidrojel pansuman, silikon meme başı kalkanları, anne sütü, meme ucunun temiz ve kuru tutulması, sıcak çay kompresi ve sıcak nemli komprestir (17-21).

Ebe ve hemşirelerin kaliteli bakım sunabilmeleri için anne sütünü arttırmaya ve meme sorunlarını gidermeye yönelik nonfarmakolojik yöntemleri uygulamaları gerekmektedir. Ancak Türkiye'de buna yönelik nonfarmakolojik yöntemlerin uygulanması ebe ve hemşireler tarafından yaygın olarak kullanılmamaktadır. Bu yüzden laktasyonu arttırmaya ve meme sorunlarını gidermeye yönelik nonfarmakolojik yöntemlerin etkinliğini ve uygulanabilirliğini tespit etmek için bu konu ile ilgili yapılmış lisansüstü tezlerin analiz edilmesine ihtiyaç duyulmuştur.

Amaç

Bu çalışmanın amacı, Türkiye'de emzirme sürecinde uygulanan nonfarmakolojik yöntemler ile ilgili yapılmış lisansüstü tezleri incelemek ve mevcut tezlerin sonuçlarını analiz ederek ebelik ve hemşirelik uygulamalarına ışı tutmak ve farkındalık oluşturmaktır. Bu amaç doğrultusunda aşağıdaki sorulara yanıt aranmıştır; nelerdir?

- Türkiye'de yapılan lisansüstü tezlerde laktasyonu arttırmaya yönelik çalışılan nonfarmakolojik yöntemler

- Türkiye'de yapılan lisansüstü tezlerde emzirmeye yönelik çalışılan nonfarmakolojik yöntemler nelerdir?

- Türkiye'de yapılan lisansüstü tezlerde meme sorunlarına yönelik çalışılan nonfarmakolojik yöntemler nelerdir?

Yöntem

\section{Araştırmanın Tipi}

$\mathrm{Bu}$ çalışma, literatüre dayalı olarak tanımlayıcı çalışma olup doküman analizi tekniği kullanılarak, 12 Ocak-22 Nisan 2021 tarihleri arasında, Yüksek Öğretim Kurulu (YÖK) Ulusal Tez Merkezi üzerinden lisansüstü tezlere ulaşlarak yapılmıştır.

\section{Arașttrmanin Evren ve Örneklemi}

Araştırmanın evrenini, YÖK Ulusal Tez Merkezi’ndeki laktasyonu ve meme sorunlarını inceleyen Ebelik, Çocuk Sağlığı ve Hastalıkları Hemşireliği, Doğum ve Kadın Hastalıkları Hemşireliği, Doğum, Kadın Sağlığı ve Hastalıkları Hemşireliği, Kadın Sağlı̆̆ı ve Hastalıkları Hemşireliği ve Hemşirelik Anabilim Dalı (ABD)'nda yapılmış tezler oluşturmaktadır ( $\mathrm{N}=37)$. Örneklemi ise dahil edilme kriterlerine uyan tüm tezler oluşturmaktadır (18 yüksek lisans tezi ve 13 doktora tezi olmak üzere $\mathrm{n}=31$ ). Tarama 13 Şubat-22 Mart 2021 tarihleri arasında yapılmış olup, araştırmaya, başlığında "laktasyon", "anne sütü", "meme", "emzirme" ve "nonfarmakolojik yöntem" kelimelerinden en az biri yer alan, deneysel veya yarı deneysel çalışma tasarım tipine sahip, yayın dili İngilizce ve Türkçe olan lisansüstü tezler dahil edilmiştir. Anne sütü/emzirme eğitimi ile ilgili ön test son test uygulanan tezler çalışmaya dahil edilmemiştir.

\section{Veri Toplama Araçları}

\section{Tez Değerlendirme Formu}

Araştırma verilerinin elde edilmesinde araştırmacılar tarafından geliştirilen Tez Değerlendirme Aracı kullanılmış̧ır (2225). Tez Değerlendirme Aracı, yazar, tez türü, $\mathrm{ABD}$, amaç, araştırma tipi, örneklem grubu, kullanılan nonfarmakolojik yöntem, değerlendirme ölçütleri ve sonuç bilgilerinin toplanmasını sağlamıştır.

Tarama Stratejisi 
Tarama, Yüksek Öğretim Kurulu (YÖK) Ulusal Tez Merkezi üzerinden yıl sınırlaması yapılmadan 13 Şubat-22 Mart 2021 tarihleri arasında yapılmış ve 2008-2020 tarihleri arasındaki tezlere ulaşılmıştır. Taramada anahtar kelimelerin seçiminde Medical Subject Headings (MESH)'ten yararlanılmış ve anahtar kelimeler "laktasyon", “anne sütü”, "meme", "emzirme" ve "nonfarmakolojik yöntemler" kelimelerinin kombinasyonundan oluşmuştur. Araştırma için belirlenen anahtar sözcüklerin taranması sonucu 37 teze ulaşılmıştır. Elde edilen tezler alınma ve dışlama ölçütlerine göre değerlendirilmiş olup altı tezin tam metnine ulaşılamamıştır. Çalışma toplam 31 tez ile tamamlanmıştır.

Verilerin Toplanmast

Tarama iki araştırmacı tarafından bağımsız olarak yapılmıştır. Çalışmada tezlerin incelenmesi ve verilerin Tez Değerlendirme Formu'na kayıt edilmesi iki yazar tarafından ayrı ayrı gerçekleştirilmiş ve elde edilen veriler daha sonra birleştirilmiştir. Bu işlem yapılırken, her bir tez ayrıntılı bir biçimde incelenmiş, herhangi bir görüş farklılığı olduğunda ortak karar verilerek uzlaşmaya varılmıştır.

Verilerinin Değerlendirilmesi

Araştırmada yer alan tezlere ilişkin verilerin çözümlenmesinde niceliksel analiz yöntemi kullanılmıştır. Elde edilen veriler, sayı ve yüzde olarak tablo biçiminde verilmiştir.

Araştırmanın Etik Yönü

Çalışmada, araştırma ve yayın etiği ilkelerine uyulmuştur.

Tablo 1. Tezlerin Tanımlayıcı Özellikleri $(n=31)$

Bulgular

\begin{tabular}{lcc}
\hline Tezin yayın yil & $\mathbf{n}$ & \% \\
\hline 2008 & 2 & 6.5 \\
2009 & 1 & 3.2 \\
2010 & 1 & 3.2 \\
2014 & 1 & 3.2 \\
2015 & 3 & 9.7 \\
2017 & 2 & 6.5 \\
2018 & 4 & 12.9 \\
2019 & 4 & 41.9 \\
2020 & 13 & 12.9 \\
\hline
\end{tabular}

\section{Tezin türü}

Yüksek lisans $\quad 18 \quad 58.0$

Doktora $\quad 13 \quad 13 \quad 42.0$

\section{Anabilim dalı}

Hemşirelik ABD $\quad 99.1$

Ebelik ABD

722.6

Kadın Sağlığı ve Hastalıkları Hemşireliği ABD $\quad 5 \quad 16.1$

Çocuk Sağlığı ve Hastalıkları Hemşireliği ABD $\quad 5 \quad 16.1$

Doğum ve Kadın Hastalıkları Hemşireliği ABD $\quad 5 \quad 16.1$

\begin{tabular}{lcc}
\hline Araştırma tipi & & \\
Deneysel & 28 & 90.3 \\
Yarı deneysel & 3 & 9.7 \\
\hline Örneklem grubu & & 54.8 \\
Anne & 17 & 22.6 \\
Yenidoğan & 7 & 22.6 \\
Anne-bebek çifti & 7 & \\
\hline
\end{tabular}

\section{Annelerim Doğum Şekli}

$\begin{array}{lcc}\text { Vajinal ve sezaryen } & 18 & 58.1\end{array}$

\begin{tabular}{lr} 
Sezaryen & 9 \\
\hline
\end{tabular}

Vajinal doğum $\quad 4 \quad 12.9$

\section{Annelerin Obstetrik Özellikleri}

Primipar ve multipar 21 
Bu çalışmaya toplam 31 tez dahil edilmiştir. Bu tezlerin 2008-2020 yılları arasında yayınlandığı, 18'inin yüksek lisans tezi olduğu, 9'unun hemşirelik, 7'sinin ebelik ABD'nda yapıldığg1, 28'inin deneysel araştırma tipinde olduğu, 17'sinin anneler ile birlikte yapıldığ 1,18 tezde vajinal ve sezaryen doğum ayrımı yapılmaksızın ve tezlerin 21 'inde de primipar ve multipar ayrımı yapılmadan çalışıldığı tespit edilmiştir (Tablo 1).

Tablo 2. Tezlerde Yenidoğanlara Uygulanan Nonfarmakolojik Yöntemler $(n=19)$ *

\begin{tabular}{lcc}
\hline Uygulanan Yöntemler & n & $\%$ \\
\hline Kanguru bakımı/ten tene temas & 10 & 52.7 \\
Müzik dinletisi (beyaz gürültü/ninni) & 4 & 21.1 \\
Emzik verme & 2 & 10.6 \\
Emzirme destek sistemi & 1 & 5.2 \\
Oral stimülasyon & 1 & 5.2 \\
Bebek masaji & 1 & 5.2 \\
\hline
\end{tabular}

* Bazı tezlerde birden fazla nonfarmakolojik yöntem kullanılmıştır.

Tablo 3. Tezlerde Anneye Uygulanan Nonfarmakolojik Yöntemler

Laktasyonu arttırmaya ve emzirmeye yönelik yapılan uygulamalar $(\mathrm{n}=$ 13)

\begin{tabular}{|c|c|c|}
\hline Progresif gevşeme egzersizi & 2 & 15.3 \\
\hline Müzik dinletisi & 2 & 15.3 \\
\hline Ayak masaj1 (refleksoloji) & 1 & 7.7 \\
\hline Lahana uygulaması & 1 & 7.7 \\
\hline Yatak içi egzersiz & 1 & 7.7 \\
\hline Oksitosin masajı & 1 & 7.7 \\
\hline Akupresür & 1 & 7.7 \\
\hline Bebeğin videosunun izletilmesi & 1 & 7.7 \\
\hline Oral hidrasyon & 1 & 7.7 \\
\hline Sakız çiğneme & 1 & 7.7 \\
\hline Transkütan Elektriksel Sinir Stimülasyon (TENS) & 1 & 7.7 \\
\hline \multicolumn{3}{|c|}{ Meme sorunlarına yönelik yapılan uygulamalar $(n=14)$} \\
\hline Anne sütü uygulaması & 4 & 28.7 \\
\hline Zeytinyağı uygulaması & 3 & 21.6 \\
\hline Lahana uygulaması & 1 & 7.1 \\
\hline Hidrojel ped uygulaması & 1 & 7.1 \\
\hline Göğüs kalkanı & 1 & 7.1 \\
\hline Memeyi temiz kuru tutma & 1 & 7.1 \\
\hline Ayva çekirdeği jölesi & 1 & 7.1 \\
\hline Sicak kompres uyguma & 1 & 7.1 \\
\hline Çay kompresi uygulama & 1 & 7.1 \\
\hline
\end{tabular}

* Bazı tezlerde birden fazla nonfarmakolojik yöntem kullanılmıştır.

Çalışmamıza dahil edilen tezlerde, laktasyonu arttırmaya ve emzirmeye yönelik uygulanan nonfarmakolojik yöntemlerin başında, progresif gevşeme egzersizi $(n=2)$ ve müzik dinletisi $(n=2)$ uygulamalarının geldiği bulunmuştur. Meme sorunlarına yönelik en sık uygulanan nonfarmakolojik yöntemler ise, anne sütü uygulaması (n=4) ve zeytinyağı uygulaması $(\mathrm{n}=3)$ olarak belirlenmiştir (Tablo 3).

Tablo 4'te tezlerin yazarları, amacı, örneklem grubu, değerlendirme ölçütleri ve sonuçları yer almaktadır. Yenidoğana uygulanan nonfarmakolojik yöntemler; kanguru bakımı/ten tene temas, müzik dinletisi (beyaz gürültü/ninni), emzik verme, emzirme destek sistemi, oral stimülsyon ve bebek masajı olup bu uygulamaların tamamının etkili olduğu bildirilmiştir. Laktasyonu arttırmaya ve emzirmeye yönelik anneye uygulanan nonfarmakolojik yöntemler; yatak içi egzersiz, progresif gevşeme egzersizi, müzik dinletisi, ayak masajı (refleksoloji), lahana uygulaması, oksitosin masajı, akupresür, bebeğin videosunun izletilmesi, oral hidrasyon, sakız çiğneme ve TENS’tir. Bunlardan, yatak içi egzersiz, oral hidrasyon ve sakız çiğnemenin laktasyon ve emzirme üzerinde etkili olmadığı ve diğer nonfarmakolojik yöntemlerin etkili olduğu belirtilmiştir. Meme sorunlarına yönelik uygulanan nonfarmakolojik yöntemler ise; anne sütü, zeytinyağı, lahana, ayva çekirdeği, hidrojel ped, sıcak kompres, sıcak çay kompresi uygulamaları, göğüs kalkanı ve 
memeyi temiz kuru tutma olup bu yöntemlerin tamamının etkili olduğu bildirilmiştir (Tablo 4). 


\section{Tablo 4. Emzirme Sürecinde Uygulanan Nonfarmakolojik Yöntemler ile ilgili Yapılmış Lisansüstü Tezler}

\begin{tabular}{|c|c|c|c|}
\hline Yazar & Örneklem Grubu & Değerlendirme Ölçütleri & Sonuç \\
\hline Akça, 2014 (26) & $\begin{array}{l}\text { Deney grubu: } 63 \\
\text { Kontrol grubu: } 64\end{array}$ & - LATCH & $\begin{array}{l}\text { Emzirme sırasında dinletilen beyaz gürültü dinletisi stresi azaltarak } \\
\text { emzirme başarısını olumlu yönde etkilediği saptanmıştır. }\end{array}$ \\
\hline $\begin{array}{l}\text { Arslan Gürcüoğlu, } \\
2020 \\
(22)\end{array}$ & $\begin{array}{l}\text { Acil ten tene temas grubu: } 30 \\
\text { Erken ten tene temas grubu: } 29 \\
\text { Kontrol grubu: } 33\end{array}$ & - IBFAT & $\begin{array}{l}\text { Acil tensel temasın, } 24 \text {. saat emzirme puanını olumlu yönde etkilediği ve } \\
\text { yenidoğanların daha erken emmeye başladığı bildirilmiştir. }\end{array}$ \\
\hline $\begin{array}{l}\text { Coşkun, } 2018 \\
(23)\end{array}$ & $\begin{array}{l}\text { Çalışma grubu: } 42 \\
\text { Kontrol grubu: } 38\end{array}$ & -Anne Sütü Takip Formu & $\begin{array}{l}\text { Kanguru bakımı uygulamasının prematüre bebeği olan ve emziremeyen } \\
\text { annelerin süt miktarını arttırmada etkili olduğu belirlenmiştir. }\end{array}$ \\
\hline Çankaya, 2018 (27) & $\begin{array}{l}\text { Uygulama grubu: } 50 \\
\text { Kontrol grubu: } 50\end{array}$ & $\begin{array}{l}\text { - LATCH } \\
\text { - Laktasyon başlama belirtilerini tespit } \\
\text { etmek için VAS }\end{array}$ & $\begin{array}{l}\text { Ayak masajı uygulamasının, sezaryen ile doğum yapan annelerde } \\
\text { laktasyonu erkenden başlattığı, emzirme başarısını ve sürecini } \\
\text { desteklediği bulunmuştur. }\end{array}$ \\
\hline Çelik, 2015 (28) & $\begin{array}{l}\text { Deney grubu: } 34 \\
\text { Kontrol grubu: } 36\end{array}$ & - LATCH & $\begin{array}{l}\text { Kaşıkla beslenen preterm bebeklerde, emzik uygulamasının emzirme } \\
\text { başarısını arttırdığı bulunmuştur. }\end{array}$ \\
\hline Çelik, 2019 (29) & $\begin{array}{l}\text { Deney grubu: } 35 \\
\text { Kontrol grubu: } 35\end{array}$ & - LATCH & $\begin{array}{l}\text { Preterm bebeklerde oral stimulasyon ve emzirme destek sisteminin, oral } \\
\text { beslenmeye ve tam anne memesine geçiş sürelerini, emzirme başarısını } \\
\text { ve taburculuk sonrası birinci ayda emmeye devam etmelerini olumlu } \\
\text { yönde etkilediği bulunmuştur. }\end{array}$ \\
\hline Çetinkaya, 2019 (24) & Uygulama grubu: 18 & $\begin{array}{l}\text { - Sağılan Süt Miktarının Ölçüm Aracı } \\
-\quad \text { Annenin A̧ğrı Şiddetinin } \\
\text { Değerlendirildiği GKÖ } \\
\text { - Annenin Rahatlama Düzeyinin } \\
\text { Değerlendirildiği GKÖ }\end{array}$ & $\begin{array}{l}\text { Angorjman gelişen annelere yapılan lahana uygulamasının, meme } \\
\text { ağrısını azalttığı ve süt miktarını önemli derecede arttırdığı bulunmuştur. }\end{array}$ \\
\hline Çullu, 2008 (30) & $\begin{array}{l}\text { Zeytinyağ1 uygulama grubu: } 35 \\
\text { Hidrojel ped uygulama grubu: } 35\end{array}$ & - Doğum Sonu 6.-14. Gün Anket Formu & $\begin{array}{l}\text { Emziren annelerde profilaktik zeytinyağı uygulamasının daha az meme } \\
\text { başı ağrısıyla ilişkili olduğu ve hidrojel pedden daha etkin olduğu } \\
\text { bulunmuştur. }\end{array}$ \\
\hline Dağl1, 2019 (31) & Uygulama grubu: 73 & - Anne Sütü Takip Formu & $\begin{array}{l}\text { Yenidoğan yoğun bakım ünitesinde prematüre bebeği yatan annelerde, } \\
\text { müziğin ve oksitosin masajının süt salınımını arttırdığ } 1 \text { tespit edilmiştir. }\end{array}$ \\
\hline Demirci, 2015 (32) & $\begin{array}{l}\text { Uygulama grubu (göğüs } \\
\text { kalkanı): } 40 \\
\text { Kontrol grubu (anne sütü): } 40\end{array}$ & - LATCH & $\begin{array}{l}\text { Göğüs kalkanı kullanımının meme başı sorunlarında özellikle çatlaklar } \\
\text { üzerinde anne sütünden daha etkili olduğu, emzirme başarısını arttırdığ1 } \\
\text { saptanmıştır. }\end{array}$ \\
\hline Gündoğdu, 2019 (33) & $\begin{array}{l}\text { Kontrol grubu: } 55 \\
\text { Yatak içi egzersiz grubu: } 48 \\
\text { Erken oral hidrasyon grubu: } 49 \\
\text { Sakız grubu: } 46\end{array}$ & - LATCH & $\begin{array}{l}\text { Sezaryen sonrası uygulanan yatak içi egzersizler, erken oral hidrasyon ve } \\
\text { sakız çiğnemenin, emzirme başarısını etkilemediği görülmüştür. }\end{array}$ \\
\hline Irmak, 2019 (25) & $\begin{array}{l}\text { Kanguru bakımı grubu: } 30 \\
\text { Bebek masaj1 grubu: } 30 \\
\text { Kontrol grubu:30 }\end{array}$ & - LATCH & $\begin{array}{l}\text { Kanguru bakımı ve bebek masajının, yenidoğanın emzirme başarısını } \\
\text { olumlu yönde etkilediği görülmüştür. }\end{array}$ \\
\hline
\end{tabular}




\begin{tabular}{|c|c|c|c|}
\hline Kabasakal, 2019 (34) & $\begin{array}{l}\text { Girişim grubu: } 45 \\
\text { Kontrol grubu: } 45\end{array}$ & $\begin{array}{l}\text { - Emzirme Öz-Yeterlik Ölçeği } \\
\text { - LATCH } \\
\text { - Günlük Süt Miktarı Kayıt Formu }\end{array}$ & $\begin{array}{l}\text { Prematüre yenidoğan annelerine düzenli şekilde uygulanan ve Watson } \\
\text { insan bakım modeliyle desteklenen kanguru bakımının, emzirme öz- } \\
\text { yeterliliğini, emzirme başarısını ve süt miktarını arttırdığı bulunmuştur. }\end{array}$ \\
\hline $\begin{array}{l}\text { Karakoç Geçici, } 2018 \\
\text { (35) }\end{array}$ & $\begin{array}{l}\text { Müdahale grubu: } 30 \\
\text { Kontrol grubu: } 30\end{array}$ & $\begin{array}{l}\text { - LATCH } \\
\text { - Emzirme Öz Yeterlilik Ölçeği }\end{array}$ & $\begin{array}{l}\text { Yenidoğan yoğun bakım ünitesinde yatan prematüre bebeklerin } \\
\text { annelerine uygulanan kanguru bakımının, annelerin emzirme öz-yeterlilik } \\
\text { ve emzirme başarısını artırdığı ve emzirme süresini uzattığı sonuçlarına } \\
\text { ulaşılmıştır. }\end{array}$ \\
\hline $\begin{array}{l}\text { Kaya Sağlık, } 2019 \\
(36)\end{array}$ & $\begin{array}{l}\text { Zeytinyağ grubu: } 40 \\
\text { Anne sütü grubu: } 40 \\
\text { Temiz kuru tutma grubu: } 40\end{array}$ & $\begin{array}{l}\text { - LATCH } \\
\text { - Meme Ucu ve Areoladaki Çatlak } \\
\text { Skorlaması }\end{array}$ & $\begin{array}{l}\text { Zeytinyağı kullanılarak yapılan meme bakımının meme başı sorunlarının } \\
\text { oluşumunu önlemeye yardımcı olduğu, anne sütü ve zeytinyağı } \\
\text { kullanılarak yapılan meme bakımının ağrıy azalttığı ve emzirme } \\
\text { başarısını olumlu yönde etkilediği bulunmuştur. }\end{array}$ \\
\hline Kelek, 2017 (37) & $\begin{array}{l}\text { Anne sütü grubu: } 142 \\
\text { Ayva çekirdeği jölesi grubu: } \\
142 \\
\text { Kontrol grubu: } 142\end{array}$ & $\begin{array}{l}\text { - Meme Bakımı ve Doğru Emzirme Tekniği } \\
\text { Kontrol Formu } \\
\text { - Meme Hijyeni Soru Formu } \\
\text { - Meme Bakımı İzlem Formu }\end{array}$ & $\begin{array}{l}\text { Anne sütü ve ayva çekirdeği jölesi uygulanan annelerde meme ba } \\
\text { sorunlarının daha az görüldüğü ve ayva çekirdeği jölesi uygulamasın } \\
\text { meme sorunlarını önlemede daha etkili olduğu bulunmuştur. }\end{array}$ \\
\hline Kır, $2020(38)$ & $\begin{array}{l}\text { Kadının söylediği ninni grubu: } \\
40 \\
\text { Erkeğin söylediği ninni grubu: } \\
40 \\
\text { Beyaz gürültü grubu: } 40 \\
\text { Kontrol grubu: } 40\end{array}$ & - LATCH & $\begin{array}{l}\text { Dinletilen ninni ve beyaz gürültünün emzirmenin başlatılmasında ve } \\
\text { emzirme başarasında etkili olduğu, emzirmenin başlatılmasında en etkili } \\
\text { yöntemin ise beyaz gürültü olduğu bulunmuştur. }\end{array}$ \\
\hline Kirlek, 2010 (39) & $\begin{array}{l}\text { Anne sütü grubu: } 13 \\
\text { Zeytinyağ1 grubu: } 13 \\
\text { Kontrol grubu: } 13\end{array}$ & - Emzirme Gözlem Formu & $\begin{array}{l}\text { Meme başı ağrısını önlemede anne sütü, meme başı çatlakların } \\
\text { önlemesinde ise zeytinyağı etkili bulunmuştur. }\end{array}$ \\
\hline Koç, 2015 (40) & $\begin{array}{l}\text { Deney grubu: } 60 \\
\text { Kontrol grubu: } 57\end{array}$ & - LATCH & $\begin{array}{l}\text { Doğumda kanguru bakımının, bebeğin emzirme başarısını arttırc } \\
\text { bulunmuştur. }\end{array}$ \\
\hline Korkut, 2017 (41) & $\begin{array}{l}\text { Deney grubu: } 56 \\
\text { Kontrol grubu: } 56\end{array}$ & - LATCH & $\begin{array}{l}\text { Doğum sonu erken dönemde uygulanan kanguru bakımının, anneler } \\
\text { emzirme başarısını, yenidoğanların emme sayısını ve süresini arttırdığ } \\
\text { emmeye başlama zamanını ise kısalttığ tespit edilmiştir. }\end{array}$ \\
\hline Öztürk, 2019 (42) & $\begin{array}{l}\text { TENS grubu: } 30 \\
\text { Progresif gevşeme egzersizleri } \\
\text { grubu: } 30 \\
\text { TENS + progresif gevşeme } \\
\text { egzersizleri grubu: } 30 \\
\text { Kontrol grubu: } 30\end{array}$ & $\begin{array}{l}\text { - LATCH } \\
\text { - Emzirme Öz-Yeterlilik Ölçeği }\end{array}$ & $\begin{array}{l}\text { TENS'in, emzirme öz-yeterliliği üzerinde, progresif gevşeme } \\
\text { egzersizlerinin ise emzirme başarısı ve emzirme öz-yeterliliği üzerinde } \\
\text { etkili olduğu bulunmuştur. }\end{array}$ \\
\hline Sar1, $2020(43)$ & $\begin{array}{l}\text { Deney grubu: } 32 \\
\text { Kontrol grubu: } 32\end{array}$ & $\begin{array}{l}\text { - Laktasyon Başlama } \\
\text { Değerlendirdiği VAS } \\
\text { - Süt Miktarı Ölçüm Tablosu }\end{array}$ & $\begin{array}{l}\text { Akupresür grubu annelerde sağılan süt miktarı kontrol grubuna göre da } \\
\text { fazladır. }\end{array}$ \\
\hline Sarıcan, 2019 (44) & $\begin{array}{l}\text { Müdahale grubu } \quad \text { (kanguru } \\
\text { bakımı ve emzirme eğitimi): } 64 \\
\text { Kontrol grubu: } 68\end{array}$ & $\begin{array}{l}\text { - Kanguru Bakımı ve Anne Sütü Alma } \\
\text { Durumu Takip Formu } \\
\text { - LATCH }\end{array}$ & $\begin{array}{l}\text { Kanguru bakımı uygulayan annelerin, emzirmeye daha erken başladığ } 1 \\
\text { emzirme başarısını arttırdığı saptanmıştır. }\end{array}$ \\
\hline Soyer, 2019 (45) & $\begin{array}{l}\text { Kontrol grubu: } 30 \\
\text { Beyaz gürültü grubu: } 30\end{array}$ & - LATCH & Beyaz gürültü emzirme başarısını olumlu yönde etkilemektedir. \\
\hline
\end{tabular}




\begin{tabular}{|c|c|c|c|}
\hline & Sessiz ortam grubu: 30 & & \\
\hline Sürücü, 2019 (46) & $\begin{array}{l}\text { Deney grubu: } 47 \\
\text { Kontrol grubu: } 41\end{array}$ & $\begin{array}{l}\text { - Emzirme Gözlem Formu } \\
\text { - IBFAT }\end{array}$ & $\begin{array}{l}\text { Sezaryen doğum yapan kadınlarda erken ten tene temasın, emzirme } \\
\text { başarısını artırdığı belirlenmiştir. }\end{array}$ \\
\hline Şahin, 2019 (47) & $\begin{array}{l}\text { Deney grubu: } 35 \\
\text { Kontrol grubu: } 35\end{array}$ & - Postpartum Emzirme Öz-Yeterlilik Ölçeği & $\begin{array}{l}\text { Progresif kas gevşeme egzersizinin, annelerin emzirme öz-yeterliliğini } \\
\text { arttırdığ } 1 \text { bulunmuştur. }\end{array}$ \\
\hline Turhan, 2020 (48) & $\begin{array}{l}\text { Deney grubu: } 12 \\
\text { Kontrol grubu: } 15\end{array}$ & - Anne Sütü Takip Formu & $\begin{array}{l}\text { Bebeğin video görüntüsünü izleyen annelerin, süt miktarı daha yüksek } \\
\text { bulunmuştur. }\end{array}$ \\
\hline Ünsal Atan, 2008 (49) & $\begin{array}{l}\text { Anne sütü grubu: } 35 \\
\text { Sicak kompres grubu: } 35 \\
\text { Çay kompresi grubu: } 35\end{array}$ & $\begin{array}{l}\text { - Emzirme Gözlem Formu } \\
\text { - Emzirme İzlem Formu }\end{array}$ & $\begin{array}{l}\text { Meme sorunlarını önlemede, sıcak nemli çay ve sıcak nemli } \\
\text { uygulamasının, anne sütü uygulamasına göre daha etkili olduğu } \\
\text { bulunmuştur }\end{array}$ \\
\hline Varışoğlu, 2019 (50) & $\begin{array}{l}\text { Deney grubu: } 20 \\
\text { Kontrol grubu: } 20\end{array}$ & - İzlem Formu & $\begin{array}{l}\text { Müziğin, doğum sonu üçüncü günden itibaren anne sütü miktarını } \\
\text { arttırdığı bulunmuştur. }\end{array}$ \\
\hline $\begin{array}{l}\text { Yaşar } \text { Kivik, } 2018 \\
(51)\end{array}$ & $\begin{array}{l}\text { Deney grubu: } 30 \\
\text { Kontrol grubu: } 30\end{array}$ & - LATCH & Erken ten tene temasın, emzirme başarısını arttırdığı bulunmuştur. \\
\hline Yildiz, 2009 (52) & $\begin{array}{l}\text { Kontrol grubu: } 30 \\
\text { Emzik grubu: } 30 \\
\text { Ninni grubu: } 30\end{array}$ & - LATCH & $\begin{array}{l}\text { Emzik verme ve ninni dinletme yöntemlerinin, emzirme başarısını } \\
\text { arttırdığı bulunmuştur. }\end{array}$ \\
\hline
\end{tabular}




\section{Tartışma}

Türkiye'de emzirme sürecinde uygulanan nonfarmakolojik yöntemler ile ilgili yapılmış lisansüstü tezleri incelemek amacıyla yapılan bu çalışmada, emzirme süreciyle ilgili yenidoğana uygulanan nonfarmakolojik yöntemlerden en çok kanguru bakımı/ten tene temas, laktasyonu arttırmaya ve emzirmeye yönelik progresif gevşeme egzersizi ve müzik dinletisi, meme sorunlarına yönelik ise anne sütü uygulaması çalışılmıştır. Bu sonuçlar Türkiye' de emzirme sürecinde uygulanan nonfarmakolojik yöntemler ile ilgili yapılmış lisansüstü tezlerin durumunu ortaya koyan ilk çalışma olması bakımından önemlidir. Son yıllarda sezaryen ve prematür doğumların artmasıyla birlikte doğum sonrası annelerde prolaktin ve oksitosin salınımının hemen gerçekleşmemesinden kaynaklı anne sütü üretimi az olmaktadır. Bu sebeplerden dolayı sezaryen sonrası emzirmeye başlama ve devam ettirme, süt üretiminde azalma ve meme sorunları yaşanmaktadır. Bunlara ek olarak bu süreçte sınırlı farmakolojik yöntemin kullanılması laktasyon, emzirme ve meme sorunları ile ilgili nonfarmakolojik yöntemlerin önemini arttırmaktadır (16).

Doğum sonrası kanguru bakımı/ten tene temas uygulamasının maternal oksitosin seviyesini arttırarak emzirmeyi olumlu yönde etkilediği belirtilmektedir $(53,54)$. Çalışmamızda yenidoğana uygulanan nonfarmakolojik yöntemlerden kanguru bakımı/ten tene temasın, emmeye başlama zamanını kısalttığı, emme sayısını, süresini ve süt miktarını arttırdığı, emzirme başarısını ve öz-yeterliliğini olumlu yönde etkilediği sonucuna ulaşılmıştır $(22,23,25,35,40,41,44,46,50,51)$. Yapılan çalışmalarda, kanguru bakımı/ten tene temasın emzirme başarısını olumlu yönde etkilediği bildirilmiştir $(55,56)$. Benzer şekilde, ten tene temasın emzirme öz-yeterliliği üzerindeki etkisini belirlemek için yapılan bir çalışmada, ten tene temasın emzirme öz-yeterliliğini olumlu yönde etkilediği, ilk emzirme zamanını kısalttığı ve emzirme oranını arttırdığı saptanmıştır (57). Bu sonuçlar doğrultusunda, kanguru bakımı/ten tene temasın, uygulanabilir, maliyetsiz ve emzirme üzerinde etkili bir yöntem olduğu söylenebilir.

İncelenen tezler sonucunda bebeğe dinletilen müziğin/beyaz gürültünün, emzirme başarısını olumlu yönde etkilediği ve emzirmenin başlatılmasında etkili olduğu sonucuna ulaşılmıştır $(26,38,45,52)$. Ayrıca çalışmaya dahil edilen tezlerin birinde beyaz gürültünün müzik dinletisinden daha etkili bir yöntem olduğu bildirilmiştir (38). Literatürde, müzik terapisinin; term ve preterm bebeklerin gelişimini desteklemesi, ekstrauterin döneme uyum sağlamalarına ve müzik ile annelerin rahatlamasına pozitif etki ederek emzirmeyi kolaylaştırdığı bildirilmektedir $(58,59)$. Annelerin bu konuda hem eğitilmesi hem de uygulamaya teşvik edilmesiyle emzirme oranlarının artmasına katkı sağlayacağı düşünülmektedir. Ayrıca literatür incelendiğinde, müzik dinletisinin laktasyon ve emzirme üzerindeki etkisini inceleyen nitel ve nicel çalışmalara ihtiyaç duyulduğu söylenebilir.

Erken dönemde ve sık sık süt sağılmasına rağmen bazı annelerde süt hacmi ve süt üretimi ilk birkaç hafta daha düşük olabilmektedir. $\mathrm{Bu}$ yüzden, yenidoğana zararsız olduğu inancından dolayı anneler nonfarmakolojik yöntemlere yönelmektedir (60). Bu yöntemler; sırt masaj1, yoga, meme masaj1, akupunktur, akupresür, gevşeme egzersizleri, müzik terapi, aromaterapi, bitkisel çay kullanımı, galaktagoglar, hipnoemzirme gibi uygulamalardır $(15,16)$. Çalışmamızda incelenen tezlerde laktasyonu arttırmaya yönelik, anneye uygulanan nonfarmakolojik yöntemlerin başında progresif gevşeme egzersizi ve müzik dinletisi gelirken, bunları yatak içi egzersiz, ayak masajı (refleksoloji), lahana uygulaması, oksitosin masajı, akupresür, bebeğin videosunun izletilmesi, oral hidrasyon, sakız çiğneme ve TENS takip etmektedir. $\mathrm{Bu}$ sonuçlar doğrultusunda yoga, akupunktur, meme masajı, aromaterapi, bitkisel çay kullanımı, galaktagoglar ve hipnoemzirme ile ilgili konuların lisansüstü tezlerde çalışılmadığı görülmektedir.

Gevşeme egzersizlerinin, emzirmede başrol oynayan oksitosin hormonunun üretimini arttırabileceği bildirilmektedir (61). İncelenen tezlerde de progresif gevşeme egzersizlerinin emzirme öz-yeterliliği ve emzirme başarısı üzerinde etkili olduğu bulunmuştur $(42,47)$. Yapılan sistematik derlemede, doğum sonu gevşeme egzersizlerinin, emzirmenin başlama ve sürdürülmesinde etkili olduğu bildirilmiştir (62). Benzer bir çalışmada da, progresif gevşeme egzersizinin emzirme öz-yeterliliği arttırdığı saptanmıştır (63). Progresif gevşeme egzersizlerinin, doğum sonu dönemde ebeler ve hemşireler tarafından verilen bakıma dahil edilerek annelerin emzirme konusunda desteklenmesi gerektiği düşünülmektedir.

Müzik ile sağlık bakımı arasında yakın bir ilişki olduğu ve müziğin, sağlı̆̆ın her alanında kullanılabileceği belirtilmektedir. Fiziksel, psikolojik ve sosyal etkileri olan müzik terapi, anksiyeteyi azaltma, gevşemeyi sağlama, bireyin konforunu arttırma ve oksitosin salınımına etki ederek anne sütü salınımını artırmada olumlu etkileri olduğu bilinmektedir (64). Çalışmaya dahil edilen tezler incelendiğinde, annelere dinletilen müziğin, süt salınımını ve miktarını arttırdığ 1 tespit edilmiştir $(31,50)$. Prematüre yenidoğanı olan annelerde müzik terapinin anne sütü miktarına etkisinin incelendiği bir çalışmada, müzik terapi uygulanan annelerin anne sütü miktarında istatistiksel olarak anlamlı bir artış saptanmıştır (65). Benzer bir çalışmada ise, doğumdan hemen sonra müzik dinleyen annelerde anne sütü miktarında istatistiksel olarak anlamlı artış bulunmuştur (66). Bu sonuçlar doğrultusunda, müzik terapinin laktasyon üzerinde olumlu etkisi olduğu söylenebilir. Ayrıca ülkemizde bununla ilgili yapılan bir çalışmaya rastlanmamış olup bu konuyla ilgili çalışmalara ihtiyaç duyulmaktadır.

İncelenen tezlerde yatak içi egzersiz, oral hidrasyon ve sakız çiğnemenin laktasyon ve emzirme üzerinde etkili olmadığı bulunmuştur (33). Çalışma bulgularımızın aksine, sezaryen doğum sonrası erken oral hidrasyonun ameliyat sonrası etkilerini inceleyen bir çalışmada, erken oral hidrasyonunun emzirme sayılarını arttırdığ tespit edilmiştir (67). Benzer bir şekilde, sezaryen sonrası erken oral hidrasyonun emzirmeye başlama zamanını kısalttığı bildirilmiştir (68). Literatür incelendiğinde ülkemizde, sakız çiğneme ve erken oral hidrasyonun laktasyona ve emzirmeye etkisini araştıran çalışmaya rastlanmamıştır. Bu doğrultuda erken oral hidrasyon ve sakız çiğnemenin laktasyon ve emzirme üzerine etkisini inceleyen çalışmalara ihtiyaç duyulmaktadır.

Emziren anneler bilgi eksikliği nedeniyle emzirirken bazı sorunlar yaşamaktadır. Emzirirken yaşanan bu 
sorunlar; düz/çökük meme ucu, meme dolgunluğu (engorjman), meme başında hassasiyet/ağrı, çatlak meme ucu, yetersiz süt salınımı, tıkanmış süt kanalları, mastit, meme absesi ve memede enfeksiyondur $(69,70)$. Bu sorunları gidermek için anneler nonfarmakolojik yöntemlere (anne sütü, zeytinyağı, lanolin krem, aloevera jeli vb.) yönelmektedir (18-21). Çalışmamızda, meme sorunlarına yönelik uygulanan nonfarmakolojik yöntemler ise; anne sütü, zeytinyağ1, lahana, ayva çekirdeği, hidrojel ped, sıcak kompres, sıcak çay kompresi uygulamaları, göğüs kalkanı ve memeyi temiz kuru tutma olduğu, bunlardan en sık anne sütü ve zeytinyağı uygulaması tercih edildiği saptanmıştır. Yapılan tezler incelendiğinde, anne sütü uygulamasının, meme başı sorunlarını azalttığ 1 ve emzirme başarısını olumlu yönde etkilediği bulunmuştur. Ayrıca incelenen tezler sonucunda meme başı ağrısını önlemede anne sütü, meme başı çatlaklarının önlemesinde zeytinyağı daha etkili bulunmuştur. Yapılan bir çalışmada, postpartum dönemde meme başına zeytinyağ uygulayan kadınlarda anne sütü uygulayan gruba göre meme başı çatlağı daha az izlenmiştir (71). Zeytinyağının meme ucu sorunları üzerindeki etkisini inceleyen çalışmalarda, zeytinyağının meme ucu sorunları önlemede güvenli, erişilebilir ve faydalı bir seçim olduğu tespit edilmiştir (72). Anne sütü ve zeytinyağının antibakteriyel, antienflamatuar etkileri ve bu ajanlar uygulanarak yapılan meme bakımının oluşturduğu nemli ortamın meme başı problemlerinin gelişmesini önleyici etkisi ile ilişkilendirilebilir.

\section{Kisitlılıklar}

Bu çalışmanın sonuçları, çalışmaya dahil edilen tezlerle sınırlıdır.

\section{Sonuçların Uygulamada Kullanımı}

Türkiye'de emzirme sürecinde uygulanan nonfarmakolojik yöntemler ile ilgili yapılmış lisansüstü tezleri incelemek amacıyla yapılan bu çalışmada, emzirme sürecinde uygulanan nonfarmakolojik yöntemler; kanguru bakımı/ten tene temas, müzik dinletisi (beyaz gürültü/ninni), emzik verme, emzirme destek sistemi, oral stimülasyon, bebek masajı, yatak içi egzersiz, progresif gevşeme egzersizi, müzik dinletisi, ayak masajı (refleksoloji), lahana uygulaması, oksitosin masaj1, akupresür, bebeğin videosunun izletilmesi, oral hidrasyon, sakız çiğneme, TENS, anne sütü, zeytinyağı, lahana, ayva çekirdeği, hidrojel ped, sıcak kompres, sıcak çay kompresi uygulamaları, göğüs kalkanı ve memeyi temiz kuru tutmadır. Bu çalışmada, emzirme sürecine yönelik nonfarmakolojik yöntemlerin laktasyona, emzirmeye ve meme sorunları üzerinde etkili oldukları tespit edilmiştir. Ancak yöntemlerin etkinliğini değerlendirebilmek için kanıt düzeyi yüksek daha fazla sayıda randomize kontrollü çalışmalara ihtiyaç duyulmaktadır. İlgili alanlarda çalışan ebe ve hemşirelerin, emzirme sürecini desteklemek ve laktasyonu arttırmak amaciyla etkinliği tespit edilen nonfarmakolojik yöntemlerle ilgili hizmet içi eğitim almaları, eğitime uygun bakım vermeleri, anne sütünün artırılmasında aktif rol alarak uygulama yapmaları ve protokol geliştirmeleri önerilmektedir. Ayrıca, emzirme sürecinde uygulanan nonfarmakolojik yöntemlerin kullanımının yaygınlaştırılması, kendi kendine uygulanabilecek yöntemler konusunda annelere eğitim verilmesi, desteklenmesi ve cesaretlendirmesi önerilmektedir.

\section{Bilgilendirme}

Bu çalışmada yazarların katkı beyan; R.K.O.: Fikir/kavram, tasarım, veri toplama ve işleme, analiz ve yorum, kaynak taraması, makalenin yazımı. Y.S.: Fikir/kavram, tasarım, veri toplama ve işleme, analiz ve yorum, kaynak taraması, makalenin yazımı. A.T.: Fikir/kavram, makalenin yazımı, eleştirel inceleme. Yazarlar arasında çıkar çatışması bulunmamaktadır. Bütün yazarlar bu makalenin son halini onaylamaktadır. Bu çalışmada finansal destek alınmamıştır. Araştırmanın bütçesi araştırmacılar tarafından karşılanmıştır. 


\section{Kaynaklar}

1. Çaka YS, Topal S, Altınkaynak S. Anne sütü ile beslenmede karşılaşılan sorunlar. Türkiye Klinikleri J Pediatr Nurs-Special Topics 2017;3(2):120-8.

2. Bransburg-Zabary S, Virozub A, Mimouni F. Human milk warming temperatures using a simulation of currently available storage and warming methods. PLoS One 2015;10(6):e0128806.

3. Victora CG, Bahl R, Barros A, França G, Horton S, Krasevec J, et al. Breastfeeding in the 21 st century: Epidemiology, mechanisms, and lifelong effect. Lancet 2016;387(10017):475-490.

4. Horta BL, Loret DE, Mola C, Victora CG. Breastfeeding and intelligence: A systematic review and meta-analysis. Acta Paediatr 2015;104(467):14-9.

5. Irmak N. Anne sütünün önemi ve ilk 6 ay sadece anne sütü vermeyi etkileyen unsurlar. Jour Turk Fam Phy 2016;7(2):27-31.

6. Köksal G, Gökmen H. Çocuk Hastalıklarında Beslenme Tedavisi, 6. Baskı Hatiboglu yayınları, 2017,31-32.

7. Oktar Ö, Çoskun MA, Bostancı S. Anne sütü mucize olmaya devam ediyor. Türkiye Klinikleri J Nurs Sci 2018;10(3):228-37.

8. Word Health Organization. European region has lowest global breastfeeding rates. 2018. URL: http://www.euro.who.int/en/health-topics/Lifestages/maternal-and-newborn-health/news/news/2015/08/whoeuropean-region-has. 22 Şubat 2021.

9. Word Health Organization. World health statistics. 2015. URL: https://www.who.int/docs/default-source/ghodocuments/world-health-statistic-reports/world-health-statistics-2015.pdf. 22 Şubat 2021.

10. Hacettepe Üniversitesi Nüfus Etütleri Enstitüsü T.C. Sağlık Bakanlığı Ana Çocuk Sağlığı ve Aile Planlaması Genel Müdürlüğü. Türkiye nüfus ve sağllk araştırması. 2018. URL: http://www.hips.hacettepe.edu.tr/tnsa2018/rapor/TNSA2018_ana_Rapor.pdf. 9 Haziran 2021.

11. Safon C, Keene D, Guevara WJU, Kiani S, Herkert D, Munoz EE, et al. Determinants of perceived insufficient milk among new mothers in León, Nicaragua. Matern Child Nutr 2017;13(3):16-25.

12. Karaçam Z, Sağlık M. Breastfeeding problems and interventions performed on problems: Systematic review based on studies made in Turkey. Turk Pediatri Ars 2018;53(3):134-48.

13. Raghavan V, Bhartı B, Kumar P, Mukhopadhyay K, Dhaliwal L.First hour initiation of breastfeeding and exclusive breastfeeding at six weeks: Prevalence and predictors in a tertiary care setting. Indian J Pediatr 2014;81:743-750.

14. Eidelman AI, Schanler RJ, Johnston M, Landers S, Noble L, Szucs K. Breastfeeding and the use of human milk. Pediatrics 2012;129(3):827- 841.

15. Sari LP, Salimo H, Budihastuti UR. Optimizing the combination of oxytocin massage and hypnobreastfeeding for breast milk production among post-partum mothers. Journal of Maternal and Child Health 2017;2(1):20-29.

16. Varışoğlu Y, Güngör Satılmış İ. Preterm doğumlarda anne sütü ve anne sütünü artırmaya yönelik alternatif yöntemler. İzmir Democracy University Health Sciences Journal 2019;2(2):99-113.

17. Amir Ali Akbardi S, Alamolhoda SH, Baghban AA, Mirabi P. Effects of menthol essence and breast milk on the improvement of nipple fissures in breastfeeding women. J Res Med Sci 2014;19:629-33.

18. As'adi N, Kariman N, Mojab F, Pourhoseinholi MA. The effect of Saqez (Pistacia atlantica) ointment on nipple fissure improvement in breastfeeding women during onemonth follow-up. Avicenna J Phytomed 2017;7(6):477485.

19. Eshgizade M, Moghaddam MB, Moghaddam HM, Mahmoudıan A, Mesbah M. Comparison of the effect of olive oil, aloe vera extract and breast milk on healing of breast fissure in lactating mothers: a randomized clinical trial. Qom Univ Med Sci J 2016;10:19-27.

20. Jackson K1, Dennıs Cl. Lanolin for the treatment of nipple pain in breastfeeding women: a randomized controlled trial. Maternal Child Nutrition 2016;1(1):1-10.

21. Vieira F, Delalibera DCF, Mota Correa Castral T, Gummaraes JV, Marques Salge AK, Bachion MM. Effects of anhydrous lanolin versus breast milk combined with a breast shell for the treatment of nipple trauma and pain during breastfeeding: A randomized clinical trial. j midwifery womens health 2017;62:572-579.

22. Arslan Gürcüoğlu E. Sezaryen sonrası anne ve yenidoğan arasında uygulanan acil ve erken tensel temasın ilk 24 saatte annenin emzirmesi, kaygısı, kanaması ve yenidoğan sağlı̆ına etkileri. Doktora Tezi. Gazi Üniversitesi, Sağlık Bilimleri Enstitüsü, Ankara, 2020.

23. Coşkun D. Prematüre bebeği olan ve emziremeyen annelerin uyguladığı kanguru bakımının annelerin stres düzeyi ve süt miktarına etkisi. Doktora Tezi, İnönü Üniversitesi, Sağlik Bilimleri Enstitüsü, Malatya, 2018.

24. Çetinkaya E. Meme dolgunluğu (angorjman) gelişen annelerde lahana uygulamasının etkisi. Doktora Tezi, Ege Üniversitesi, Sağlık Bilimleri Enstitüsü, İzmir, 2019.

25. Irmak G. Yenidoğanlarda Kanguru Bakımı ve Masajın Emme Başarısı Ve Fiziksel Parametrelere Etkisi. Yüksek Lisans Tezi. Düzce Üniversitesi, Sağlık Bilimleri Enstitüsü. Düzce, 2019.

26. Akça K. Beyaz gürültünün yenidoğanlarda emme başarısına etkisi. Yüksek Lisans Tezi, Atatürk Üniversitesi, Sağlık Bilimleri Enstitüsü, Erzurum, 2014.

27. Çankaya S. Sezaryenla doğum yapan annelerde ayak masajının laktasyona ve doğum sonu konfora etkisi; randomize kontrollü çalışma. Doktora Tezi. İstanbul Üniversitesi, Sağlık Bilimleri Enstitüsü, İstanbul, 2018. 
28. Çelik V. Preterm bebeklerde emzik verme yönteminin tam anne memesine geçiş ve emme başarısı üzerine etkisi. Yüksek Lisans Tezi, Atatürk Üniversitesi, Sağlık Bilimleri Enstitüsü, Erzurum, 2015.

29. Çelik F. Preterm bebeklerde oral stimulasyon ve emzirme destek sisteminin tam anne memesine geçiş süresi ve emme başarısı üzerine etkisi: Randomize kontrollü çalışma. Yüksek Lisans Tezi, Manisa Celal Bayar Üniversitesi, Sağlık Bilimleri Enstitüsü, Manisa, 2019.

30. Çullu R. Meme bakımında kullanılan zeytinyağı ve hidrojel ped uygulanmasının meme bası sorunlarının önlenmesine etkisi. Yüksek Lisans Tezi, Gazi Üniversitesi Sağlık Bilimleri Enstitüsü. Ankara, 2008.

31. Dağlı E. Yenidoğan yoğun bakım ünitesinde yatan prematüre bebeklerin annelerinde müziğin ve oksitosin masajının süt salınımına etkisinin değerlendirilmesi. Doktora Tezi. Eskişehir Osmangazi Üniversitesi, Sağlık Bilimleri Enstitüsü. Eskişehir, 2019.

32. Demirci G. Doğum sonrası meme başı çatlaklarının oluşumunun önlenmesinde göğüs kalkanı kullanımının etkisi. Yüksek Lisans Tezi. Marmara Üniversitesi, Sağlık Bilimleri Enstitüsü, İstanbul, 2015.

33. Gündoğdu G. Sezaryen sonrası uygulanan yatak içi egzersizler, erken oral hidrasyon ve sakız çiğnemenin bağırsak hareketleri ile ağrı ve emzirmeye etkisi. Doktora Tezi. Atatürk Üniversitesi, Sağlık Bilimleri Enstitüsü, Erzurum, 2019.

34. Kabasakal A. Prematüre Bebek Annelerinde Watson'ın Modeli İle Uygulanan Kanguru Bakımının Laktasyon Sürecine ve Kaygı Düzeyine Etkisi. Doktora Tezi. Gazi Üniversitesi Sağlık Bilimleri Enstitüsü. Ankara, 2019.

35. Karakoç Geçici A. Prematüre Bebeklerde Kanguru Bakımının Annelerin Emzirme Öz-Yeterlilik ve Emzirme Başarısına Etkisi. Yüksek Lisans Tezi. Necmettin Erbakan Üniversitesi, Sağlık Bilimleri Enstitüsü. Konya, 2018.

36. Kaya Sağlık D. Emzirme döneminde meme bası sorunlarının önlenmesinde, zeytinyağı, anne sütü ve temiz kuru tutma yöntemi kullanılarak yapılan meme bakımı yöntemlerinin etkinliğinin incelenmesi. Yüksek Lisans Tezi. Afyonkarahisar Sağlık Bilimleri Üniversitesi, Lisansüstü Eğitim Enstitüsü. Afyon, 2019.

37. Kelek S. Erken postpartum dönemde kullanılan ayva çekirdeği jölesi ve anne sütünün meme başı çatlağı oluşumuna etkisi. Yüksek Lisans Tezi. Cumhuriyet Üniversitesi, Sağlık Bilimleri Enstitüsü, Sivas, 2017.

38. Kır E. Yenidoğanlarda ninnilerin ve beyaz gürültünün emzirmenin başlatılması üzerine etkisinin karşıllaştırılması. Yüksek Lisans Tezi. Tokat Gaziosmanpaşa Üniversitesi, Sağlı Bilimler Enstitüsü. Tokat, 2020.

39. Kirlek F. Erken postpartum dönemde meme başı ağrısı ve çatlaklarının önlenmesinde anne sütü ve zeytinyağının etkisi. Yüksek Lisans Tezi. Adnan Menderes Üniversitesi, Doğum ve Kadın Sağlığı ve Hastalıkları Hemşireliği. Aydin, 2010.

40. Koç S. Doğumda kanguru bakımının yenidoğanın emzirme davranışlarına ve annenin konfor düzeyine etkisi. Yüksek Lisans Tezi. İstanbul Medipol Üniversitesi, Sağlık Bilimleri Enstitüsü. İstanbul, 2015.

41. Korkut S. Doğum sonu erken dönemde sağlıklı yenidoğanlara uygulanan kanguru bakımının emzirmeye etkisi. Yüksek Lisans Tezi. İstanbul Üniversitesi, Sağlık Bilimleri Enstitüsü. İstanbul, 2017.

42. Öztürk D. Sezaryen ile doğum yapan kadınlara uygulanan progresif gevşeme egzersizleri ve transkütan elektriksel sinir stimülasyonunun akut ağrı, emzirme davranışı ve konfor düzeyine etkisi; randomize kontrollü çalışma. Doktora Tezi. Hacettepe Üniversitesi, Sağlık Bilimleri Enstitüsü. Ankara, 2019.

43. Sarı E. Preterm sezaryen doğum sonrası emziremeyen annelere uygulanan akupresürün laktasyona etkisi. Doktora Tezi. İstanbul Üniversitesi, Cerrahpaşa Lisansüstü Eğitim Enstitüsü, İstanbul, 2020.

44. Sarıcan ES. Doğumda kanguru bakımının sadece anne sütü ile beslenme durumuna ve bebeğin büyümegelişmesine etkisinin bağlanma kuramına göre incelenmesi. Doktora Tezi. Ege Üniversitesi, Sağlık Bilimleri Enstitüsü. İzmir, 2019.

45. Soyer S. Beyaz gürültü ve sessiz ortamın yenidoğanın emme başarısına etkisi. Yüksek Lisans Tezi. Balıkesir Üniversitesi Sağlık Bilimleri Enstitüsü, Balıkesir, 2017.

46. Sürücü ZS. Sezaryen doğum yapan kadınlarda, erken ten tene temasın, emzirme ve doğum sonu kanama üzerıne etkisinin değerlendirilmesi. Yüksek Lisans Tezi. Marmara Üniversitesi, Sağlık Bilimleri Enstitüsü. İstanbul, 2018.

47. Şahin K. Preterm bebek annelerine uygulanan progresif kas gevşeme egzersizlerinin anne ve bebek üzerine etkisi. Yüksek Lisans Tezi. İstanbul Üniversitesi, Cerrahpaşa Lisansüstü Eğitim Enstitüsü. İstanbul, 2019.

48. Turhan İ. Bebeği yenidoğan ünitesinde yatan annelere bebeğinin video görüntüsünün izletilmesinin anne sütü ve maternal bağlanmaya etkisi. Erciyes Üniversitesi Sağllk Bilimleri Enstitüsü. Kayseri, 2020.

49. Ünsal Atan Ş. Primipar emziren annelerde meme ucu sorunlarının önlenmesinde farklı yöntemlerin etkinliğinin incelenmesi. Doktora Tezi. Ege Üniversitesi Sağlk Bilimleri Enstitüsü. İzmir, 2008.

50. Varışoğlu Y. Yenidoğan yoğun bakım ünitesinde prematüre bebeği olan annelere dinletilen müziğin anne sütü üretimine etkisi. Doktora Tezi. İstanbul Üniversitesi, Cerrahpaşa Lisansüstü Eğitim Enstitüsü. İstanbul, 2019.

51. Yaşar Kivik S. Epidural anestezi ile doğum yapan primipar annelerde erken ten temasının emzirme üzerindeki etkisi. Yüksek Lisans Tezi. Bülent Ecevit Üniversitesi, Sağllk Bilimleri Enstitüsü. Zonguldak, 2018.

52. Yıldız A. Prematüre bebeklerde emzik verme ve ninni dinletme yöntemlerinin total oral beslenmeye geçiş süresi ve emme başarısı üzerine etkisi. Doktora Tezi. Atatürk Üniversitesi, Sağlık Bilimleri Enstitüsü. Erzurum, 2009.

53. Karimi FZ, Heidarian Miri H, Salehian M, Khadivzadeh T, Bakhshi M. The effect of mother-1nfant skin to skin contact after birth on third stage of labor: A systematic review and meta-analysis. Iranian Journal Of Public Health 2019;48(4):612-620.

54. Saxton A, Fahy K, Rolfe M, Skinner V, Hastie C. Does skin-to-skin contact and breast feeding at birth affect the rate of primary postpartum haemorrhage: Results of a cohort study. Midwifery 2015;31(11):1110-1117. 
55. Saunders Moore E R, Bergman N, Anderson GC, Medley N. Early skin-to-skin contact for mothers and their healthy newborn infants. Cochrane Database Systematic Review 2016;11(1):1-123.

56. Ding L, Shan C, Wang Y, Luo S. Effect of kangaroo mother care on breastfeeding andbehavior of full-term newborn. Chinese Journal Of Practical Nursing. 2018;34(24):1877-1882

57. Aghdas K, Talat K, Sepideh B. Effect of immediate and continuous mother-infant skin-to-skin contact on breastfeeding self-efficacy of primiparaous women: A randomised control trial. Women and Birth 2014;27:37-40.

58. Keith DR, Weaver BS, Vogel RL. The effect of music-based listening interventions on the volume, fat content and caloric content of breast milk-produced by mothers of premature and critically infants. Advances in Neonatal Care 2012;12(2):112-119.

59. Vianna MN, Barbosa AP, Carvalhaes AS, Cunha AJ. Music therapy may increase breastfeeding rates among mothers of premature newborns: A randomized controlled trial. Jornal de Pediatria, 2011;87(3):206-212.

60. Emmanuel EN, Sun J. Health related quality of life across the perinatal period among Australian women. Journal of Clinical Nursing 2014,23(11/12), 1611-1619.

61. Lawrence RA, Lawrence RM. Breastfeeding. 8. Edition. Lawrence RA. Philadelphia: W.B. Saunders; $2011: 291$.

62. Fotiou C, Siahanidou T, Vlastarakos PV, Tavoulari EF, Chrousos G. The effect of body andmindstress-releasing techniques on the breastfeeding of full-term babies; A criticalanalysis of published interventional studies. J Matern Fetal Neonatal Med 2018;31(1):98-105.

63. Karbandi S, Hosseini SM, Hosseini SA, Sadeghi F, Hesari M, Masoudi R. Evaluating the effectiveness of using a progressive muscle relaxation technique on the self-efficacy of breastfeeding in mothers with preterm infants. Journal of Nursing Research 2017;25(4):283-288.

64. Montaseri S, Zarei Z, Edraki M, Pourarian S, Ahmad SP. The effect of music therapy on breast milk secretion in mothers with premature infants. Pharmacophore 2017;8(6):1-13.

65. Jayamala AK, Lakshmanagowda PB, Pradeep GCM, Goturu J. Impact of music therapy on breast milk secretion in mothers of premature newborns. Journal of clinical and diagnostic research: JCDR 2015;9(4):4-6.

66. Kittithanesuan Y, Chiarakul S, Poovorawan Y. Effect of music on 1mmediately postpartum lactation by term mothers after giving birth: A randomized controlled trial. J Med Assoc Thai 2017;100(8):834-42.

67. Ahmed HA, El-Shahawy AA, Sammour HM. Effect of immediate versus early oral hydration on caesarean section postoperative outcomes: A randomized controlled trial. The Egyptian Journal of Hospital Medicine 2018;72(10):5409-14.

68. Gad Mohamed AH, Kamel Gudia AD. The effect of early versus delayed oral hydration on post cesarean maternal outcome and satisfaction. The Malaysian Journal of Nursing 2018;9(4):1-10.

69. Akter S, Tasnim S, Bhuiyan MMA, Hasan A. A study on postpartum breast problems of mothers attending at lactation management center (LMC). Bangladesh Med J 2015;44(3):136-139.

70. Yazıcı S, Kaya L, Kaya Z. Yenidoğan yoğun bakımda bebekleri olan annelerin meme problemleri. J Health Pro Res 2020;2(3):121-127.

71. Cordero MJ, Villar NM, Barrilao RG, Cortés ME, López AM. Application of extra virgin olive oil to prevent nipple cracking in lactating women. World views Evid Based Nurs 2015;12(6):364-369.

72. Nageeb H, Fadel EA, Hassan NF. Olive oil on nipple trauma among lactatıng mothers. Mansoura Nursing Journal 2019;6(1):159-170. 